\title{
Könyvszemle
}

SIPOS JÚLIA GNDOZÁSÁBAN

\section{RANGSORBA ÁLLÍTVA}

Érdi Péter az Eötvös Loránd Tudományegyetemen végzett magyar-amerikai fizikai kémikus, a Kalamazoo College (Kalamazoo, Michigan) komplex tudományok Henry R. Luce Professzora. Tudományterülete a kémiai kinetika, a számítógépes idegtudomány és a komplex rendszerek. Széles körű érdeklődését jól jellemzi legújabb könyve, amely a rangsorkészítés miértjeit és hogyanjait boncolgatja, miközben panoramikus képet mutat be egész sor tudományos és társadalmi kérdésröl. A könyv 119. oldalán megfogalmazott fő céljának a szubjektív és az objektív közötti lavírozás rejtett szabályainak feltárását tekinti. Teszi ezt informatív és olvasmányos, mondhatni, szórakoztató módon, továbbá takarékosan: a 246 oldalas, kis méretü, viszonylag rövid könyv hatalmas területet ölel fel. A könyv a legjobb értelemben vett sajátos potpourri. Egymástól távoli területek között teremt kapcsolatot és összefüggést a rangsorolás, a listakészítés, az értékmérés és természetesen ezek illúziója. Számomra a könyv legföbb jellemzője, hogy állandóan párbeszédre készteti az olvasót, és ezzel elejétől végig ébren tartja az érdeklődést. A könyv messze nemcsak tudománnyal foglalkozóknak szól, de recenziómban elsősorban ezek a vonatkozásai kapnak hangsúlyt.

A könyvben feltünik sok magyar vonatkozás. Ez nem meglepö, és szimpatikus. A szerző pályájának nagy részét Budapesten töltötte, és amerikai professzorsága alatt is alkotó kapcsolatban maradt a magyar tudományos élettel. Megjelenik Arany János, Arany László, Barabási Albert-László, Bartók Béla, Bródy András, Czibor Zoltán, Erdős Pál, Imre Géza, Jánossy Ferenc, Kökény Beatrix, Lukács György, Puskás Ferenc, Rényi Alfréd, Szentágothai János (Érdi egyik mentora) és mások. Szerepel a németekkel szemben az 1954-es labdarúgó világbajnoki döntőben elszenvedett 2:3-as vereség (ami az én generációmnak mind a mai napig traumatikus emlék) és az elötte 8:3-ra megnyert mérkőzés, a 2018-as országgyülési választásokhoz vezető kampány, a magyarországi öngyilkosságok számának alakulása, Magyarország szomorú helyezése a Freedom House értékelésében az országok demokrácia jellemzésében és mások.

Érdi nagyszerủ példát talál az objektív rangsorba állításra az Erdős-számban, amit pontos meghatározás szerint állapítanak meg. 512 matematikus Erdős száma 1. Ők Erdős Pállal társzerzők voltak. Erdős-szám 2-t körülbelül tízezer matemati- 
kus mondhat magáénak, akik Erdős valamelyik társszerzőjével publikáltak közösen, de Erdőssel nem. A sor így folytatódik. A matematikusok körében nagy érték az alacsony Erdős-szám. Hozzáteszem, hogy Lax Péter, korunk egyik kiemelkedő matematikusa büszke arra, hogy Erdős száma az egyedülálló 1/2. Ugyan nem publikált Erdőssel, de Erdős egyik cikkében lábjegyzetben hivatkozott Laxra.

Érdi foglalkozik a fizikai attribútumok jelentőségével a társadalmi szituációkban. Megjegyzi például, hogy a magas testalkat előnyös, ha valaki ezredes vagy elnök szeretne lenni. Mielött legyintenénk, vagy politikai inkorrektséget emlegetnénk, hozzáteszem, hogy Szilárd Leónak is ez volt a véleménye. Szilárdnak kitűnő érzéke volt a tárgyalási helyzetek maximális kihasználásához, és fontos tárgyalásaira gyakran megával vitte valamelyik magas kollégáját vagy barátját, ma úgy mondanánk, biodíszletnek.

A rangsorolással és sorrendkészítéssel esetenként megjelenő értelmetlen hiúság szomorú példájaként említ a szerző egy Donald Trumppal kapcsolatos valószínűtlenül hangzó, de dokumentált esetet. A 2001. szeptember 11-i terrortámadás ledöntötte a Világkereskedelmi Központot New Yorkban. Ezt követően Trump azzal kérkedett, hogy immár a Trump-torony lett a város legmagasabb épülete, ami ráadásul nem is volt igaz. Érdi arra is nagyszerủ példát hoz, amikor nem szabad, de legalábbis nem kellene hogy legyen rangsorbeli megkülönböztetés. Ez a demokráciákban megvalósuló fékek és ellensúlyok rendszere. Ennek megfelelően a három hatalmi ágazat, a törvényhozás, a végrehajtó hatalom és a bíráskodás egymással egyenjogú és egyik sem kerekedhet a másik fölé. Az autoriter rendszerek jellemzője, hogy megbomlik a fékek és ellensúlyok rendszere, ami rendszerint azzal is együtt jár, hogy valaki mindent tudónak, minden eldöntésére képesnek tartja magát, és ezt elfogadtatja a társadalommal, illetve ezt rákényszeríti a társadalomra. A könyv idézi Bertrand Russelt, aki szerint buták azok, akik mindenben biztosak, míg azokat, akiknek kételyeik vannak, fantázia és a dolgok megértése jellemzi. Idézi továbbá Konfuciuszt, aki szerint az igazi tudáshoz szükség van tudatlanságunk mértékének felismerésére. Álljon itt továbbá egy példa a könyvből annak illusztrálására, hogy mennyire értelmetlen, sőt káros lehet rekordok hajhászása. A szovjet ötéves tervekben gyakran fejezték ki tonnákban a teljesítményt. Így hoztak létre olyan csillárokat, amelyek lerántották a mennyezetet és olyan háztetőket, amelyek alatt összedőlt az épület.

A könyv 6. és 7. fejezete a tudományos kutatók számára központi kérdésekkel foglalkozik. A 6. fejezetben tárgyalja az egyetemek rangsorolásának hasznát és buktatóit. Ezek jórészt ismertek, de a könyv témája szempontjából a bemutatás fontos szempontokat hangsúlyoz. Így például azt, hogy a továbbtanulásra készülő fiatal számára csak általános útmutatást jelenthet a sokszor nem is egyértelmü szempontok alapján összeállított rangsor. Legalább annyira fontos az egyéni érdeklődést és komfortérzetet figyelembe venni. Mint ahogy minden ilyen esetben, 
valóban csak általános tájékozódásra alkalmasak ezek a rangsorok, és nem szabad őket túl komolyan venni. Nagy hagyományokkal és megállapodott társadalmi viszonyokkal bíró országokban kellő tartózkodással kezelik ezeket a rangsorokat. A tartózkodás azért is indokolt, mert sokféle rangsor van, amelyekben kis különbségek nagy rangsorbeli eltérésként jelenhetnek meg. Csínján kell bánni az olyan változtatásokkal, amelyek a rangsorolás szempontjait, de nem az egyetem hosszú távú érdekeit veszik figyelembe. A rövid távú hatásokra vonatkozó döntések bizonytalanságot okoznak, és mire következményük jelentkezett, esetleg a szempontok már megváltoztak, és az egész törekvés a szó igazi értelmében vett sziszifuszi munka lesz.

A folyóiratok rangsorba állítása és impaktfaktora, és ezzel összefüggésben az egyes kutatók teljesítményének ellentmondásos kvantifikálása különösen sok vitát eredményez. Ezzel a 7. fejezet foglalkozik. Itt megint elmondható, hogy fontos számokkal is kifejezni egy folyóirat és egy kutató minőségét és teljesítményét, de ezeket a számokat nem szabad észszerütlenül mindenhatónak tekinteni. Hozzáteszem, hogy sok-sok évvel ezelött a hazai akadémikusválasztásoknál az ilyenfajta teljesítmény alig volt szempont. Aztán szempont lett, de az adatokat igyekeztek diszkréten kezelni. Mostanában már minden adat nyilvános, és két problémával is meg kell küzdenünk ezzel kapcsolatban. Az egyik ezeknek az adatoknak vakon történő alkalmazása. A másik a tüzetes vizsgálódás ellenére történő teljes semmibevétele. Az idézettségi adatok jelentésének árnyalására folyamatosan jelennek meg finomítások vagy újabb és újabb módszerekkel kiszámított mutatók, esetleg tudományterületekre specifikusan alkalmazott mutatók. Vannak ragyogó példák arra, hogy mennyire nem lehet vakon alkalmazni az idézettségi adatokat. A könyvben szereplő példák kiegészítésére két továbbit teszek hozzá. Az egyik Oliver H. Lowry (1910-1996) teljesítménye, akinek egy 1951-ben a fehérjék meghatározására kidolgozott módszert közlő cikkére 2015-ös adatok szerint már 310 ezer hivatkozás született. Lowry hivatkozási adatait a különböző kimutatásokból ki szokták venni, mert minden felmérést értelmetlenné tenne. Egyébként Lowry más nagy idézettségű cikkeket is publikált, h-indexe 91. A másik példa Dmitrij Mengyelejev cikke az elemek periódusos rendszeréröl (több cikke volt erről, amelyek közül a legfontosabbnak az 1869-ben a Zeitschrift für Chemie-ben megjelent cikkét tekintik), amelynek anyaga beépült a kémia tudományába, mindenütt ott van akár kimondva, akár nem, de amelyre hivatkozás alig történik.

A tudósok rangsorolása népszerü foglalatosság. Itt is saját példákkal szeretném erősíteni a könyv mondanivalóját. Az ismert, tudományt népszerüsítő szerző, Isaac Asimov, az 1970-es évek közepére kialakított egy hetvenkét tudósból öszszeállított listát, és ebből választotta ki minden idők tíz legnagyobb tudósát. Arra már ő sem vállalkozott, hogy közöttük is rangsort állítson fel. Asimov tíz neve ábécérendben: Arkhimédész, Charles Darwin, Albert Einstein, Michael Faraday, Galileo Galilei, Antoine Lavoisier, James Clark Maxwell, Isaac Newton, Louis 
Pasteur és Ernest Rutherford. Kármán Tódor szerint a tudósok nagyságát jelentős eredeti ötleteik számával lehet mérni. Első helyre Newtont tette öt vagy hat ötlettel, utána következett Einstein négy vagy öt ötlettel. A többi nagy tudóshoz egy vagy két nagy ötletet rendelt, míg saját magához hármat vagy három és felet. Wigner Jenő is Newtont és Einsteint helyezte mindenki fölé. Utánuk következtek Wigner kortársai, Max von Laue, Walther Nernst, Polányi Mihály és Wolfgang Pauli. Wigner saját magát ebben a sorban vagy kicsit alatta képzelte el. Lev Landauról ismert, hogy mindenben rangsort alkotott. Az elméleti fizikusok között meredeken csökkenő skálát vezetett be. Az élre Einsteint helyezte, és Newtont Einsteinnel azonos kategóriába sorolta. A következő fokozat ötszörös csökkenést jelentett, és ide sorolt tizenhárom fizikust, de közülük csak nyolc nevét tudjuk biztosan. Ezek: Niels Bohr, Enrico Fermi, Werner Heisenberg, Wolfgang Pauli, Erwin Schrödinger, Paul Dirac, Max Planck és Louis de Broglie. Landau saját magát a következő kategóriába helyezte, amely megint ötször alacsonyabb szint lett volna. Később azonban Bohrék kategóriájához közelebb helyezte el magát.

A könyv foglalkozik a siker és a siker elörejelzésének kérdésével. Winston Churchillt idézi, aki szerint (hevenyészett fordításomban) a siker sohasem végleges, a kudarc sohasem végzetes, és csak a folytatás bátorsága számít. Valóban, egy tudományos kutató valószínüleg nem elég fantáziadús vagy bátor, ha csak olyan kísérleteket tervez, amelyek mind sikeresek, csak olyan modelleket alkot, amelyek mind működnek, és csak olyan kutatásokat végez, amelyek biztos eredményt hoznak, netán mindig a várt (!) eredményt.

Érdi Péter könyvét megírni nem volt kockázat nélküli vállalkozás. Megérdemli a sikert, nagy területet ölel fel, széles körủ az irodalmi merítése, ugyanakkor nem bújik el mások véleménye mögött. Gondolatébresztő, az olvasót alkotótársnak tekinti, és olvasmányos. Nem minden könyvről lehet mindezt elmondani.

(Péter Érdi: Ranking. The Unwritten Rules of the Social Game We All Pay. New York: Oxford University Press, 2020, 246 o.)

Hargittai István

kémikus, tudománytörténész az MTA rendes tagja 